\title{
Board of Directors' Characteristics and Tax Aggressiveness: Evidence from Jordanian Listed Firms
}

\author{
Luai Aburajab1', Bassam Maali1, Monther Jaradat ${ }^{2}$, Malek Alsharairi1 \\ ${ }^{1}$ Department of International Accounting, German Jordanian University, Amman, Jordan \\ ${ }^{2}$ Income and Sales Tax Department, Amman, Jordan \\ Email: Luai.Aburajab@gju.edu.jo, bassam.maali@gju.edu.jo, Montherj1974@hotmail.com,malek.alsharairi@gju.edu.jo
}

How to cite this paper: Aburajab, L., Maali, B., Jaradat, M. and Alsharairi, M. (2019) Board of Directors' Characteristics and Tax Aggressiveness: Evidence from Jordanian Listed Firms. Theoretical Economics Letters, 9, 2732-2745.

https://doi.org/10.4236/tel.2019.97171

Received: September 16, 2019

Accepted: October 25, 2019

Published: October 28, 2019

Copyright $\odot 2019$ by author(s) and Scientific Research Publishing Inc. This work is licensed under the Creative Commons Attribution International License (CC BY 4.0).

http://creativecommons.org/licenses/by/4.0/

\begin{abstract}
This study aims to examine the relationship between Board of Director's characteristics and tax aggressiveness. Taxes are considered an additional cost to the firm and its shareholders because these taxes reduce the available cash flow. Firms tend to employ different tax aggressiveness techniques. Aggressive tax planning or strategic tax behaviors are activities generally designed to reduce tax liability that includes Tax evasion, Tax evasion and legitimate saving of taxes. This study is the first in Jordan which tests the relationship between Board of Director's characteristics (Board Duality, Board Composition and Board Independence) on tax aggressiveness. Based on a sample of 140 Jordanian firms during the period 2013-2017, this study used regression analysis to examine the effect of board composition, board independence, CEO duality, return on assets (ROA) and firm size on the tax aggressiveness. The study found that there is a negative relationship between board composition and board independence from one side, and the tax aggressiveness from the other side. Furthermore, the study found that there is a positive relationship between board duality and tax aggressiveness. Finally, both the return on assets (ROA) and the firm size variables, which were included as control variables, were found to be positively related to the tax aggressiveness.
\end{abstract}

\section{Keywords}

Corporate Governance, Tax Aggressiveness, Board Size, Board Independence, Board Compensation

\section{Introduction}

Research in the area of corporate governance has a well-established history that 
dates back to 1932 [1] [2]. This was followed by a series of works in the field of agency theory [3], Incomplete Contract Theory [4] [5] [6] [7], Transaction Cost Theory [4] [5], and property right theory [6]-[10]. Due to the significant role, corporate governance can play in organizations, the last three decades have witnessed a growing interest in investigating the dynamic interaction of corporate governance [11] with the firms' economics, performance, corporate reporting, strategic management and the regulatory context.

In the same vein, corporate governance interacts with the corporate taxation where several potential implications may exist. It could be argued that corporate tax acts as a corporate governance mechanism by discouraging those behaviors that are contrary to the interests of the company or the interests of the company's stakeholders. In addition to another set of these, issues are ways to ensure the quality of management decisions in general and transparency of decisions related to the tax area in particular. Furthermore, the board of directors and stakeholders must be aware of the risks of tax administration [12].

Since taxes are considered as an additional cost to the firm and its shareholders because these taxes reduce the available cash flow, firms tend to employ different tax aggressiveness techniques. Aggressive tax planning or strategic tax behaviors are activities generally designed to reduce tax liability that includes Tax evasion and legitimate saving of taxes. It could be argued that the dollar saved through an aggressive tax practice is an extra dollar available to shareholders because aggressive taxation leads to tax savings in the short term [13].

Our contribution to the literature is motivated by the lack of research in the less developed countries on how corporate tax rules affect corporate governance. Corporate governance techniques may affect corporate tax strategies, which affect decision-making related to tax strategies [14] [15]. Shareholders seek to minimize tax payments in order to maximize the value of the company, and therefore shareholders seek tax aggressiveness to achieve these goals. However, researchers found that firms that have higher levels of institutional ownership are less tax aggressive due to the interest of business owners in the long-term consequences of aggressive tax strategies [13]. For example, the company's average share price falls when there are reports of the company's involvement in tax havens [16]. [17] identified two main reasons for examining the intersection of corporate governance mechanisms and tax shelter, where managers and executives play a key role in choosing a tax shelter policy. The first reason is that planned tax accommodation is important for maximizing value activities as a result of tax cuts and improved company performance. The second reason is the uncertainty that the tax sheltering process will be directly involved in improving the company's performance. As a result, this issue should be approached from a long-term strategic perspective while understanding how corporate governance relates to tax shelter [18]. [19] suggested that the tax aggressiveness can appear in two basic ways, the first is the legal way, which is in accordance with the law and the second is to do the tax sheltering. [20] mentioned that the level of tax aggressiveness relies on the nature and extent of the agency conflict. Further- 
more, the costs of tax aggressiveness are not tax-related like costs which appear to hide actions of managers. The analysis of the decision to tax aggressiveness is generally directly related to the agency, in which managers can benefit from additional benefits at the expense of other shareholders [16].

It is still unclear whether the aforementioned relationships hold in a developing country setting, where the context of both corporate governance and tax is substantially different from the developed countries where the market-based financial system is dominant. In Jordan, rules of corporate governance for shareholding companies listed at Amman Stock Exchange (ASE) were first issued as the "CG Code for Listed Companies" in 2008. Corporate governance in Jordan is still developing and the corporate practice of corporate governance in Jordan is still not well understood. For this, the relationship between corporate governance structure and tax aggressiveness is still unclear and has not been well investigated in a developing country context like Jordan [21]. For this reason, this study contributes to the literature by examining the relationship between ownership structure and tax aggressiveness in Jordan. This study fills in the literature gaps and follows the previous studies that have applied new methodologies to measure tax shelter and the ways in which we can identify the most aggressive activities.

In our study, we adopt the agency theory perspective to examine the relationship between corporate governance indicators as reflected by the board of directors' composition, independence, and CEO duality from one side, and the tax aggressiveness. Literatures have examined the importance of corporate regulatory factors such as corporate governance, but there is still a lack of studies on corporate governance and their relationship to taxation [21]. Most of these studies focus on the role of corporate characteristics in tax planning [17] [22] [23]. This study documents how the variation in firms' corporate governance techniques can explain the differences in the levels of tax aggressiveness in Jordanian firms. Moreover, this study provides evidence on the possible factors that affect the aggressiveness of tax planning.

The remainder of this paper is structured as follows: Section 2 is devoted to discussing the relevant literature and developing the research hypotheses. Section 3 discusses the methodology. Section 4 discusses the results of the empirical study. The paper concludes in Section 5.

\section{Literature Review and Hypotheses Development}

Literature to date discussed the effect of different corporate governance elements and firms' specific characteristics on tax aggressiveness. On a study of a sample of 73 French companies on the SBF 120 index for the period 2006-2010, [24] found board size and the percentage of women in the board affect the activity of tax aggressiveness, while return on assets and size of the firm are significantly and positively associated. [25] analyzed a sample of 355 Brazilian companies listed on the BM \& FBOVESPA between 2008 and 2014 and found that that the remuneration paid to executives may be regarded as a characteristic influencing 
tax management in Brazilian firms. [26] analyzed data from 20 manufacturing companies listed on the Nigerian Stock Exchange for 10years (2006-2016), and found that there is no significant relationship between board size and tax aggressiveness. In this study, we focus on the effect of three corporate governance variables: board composition, board independence, and CEO duality as explained bellow.

Literature on the relationship between corporate governance and tax aggressiveness have not directly examined elements of corporate governance such as those of the board of directors with tax aggressiveness [27] [28] [29] [30]. Although tax administration recognizes the importance of the board as an effective internal control tool to reduce tax aggressiveness, previous studies have not done much about the relationship of board characteristics with tax aggressiveness [31] and [32]. In practice, tax administration within an entity is the prerogative of the Board of Directors, and therefore, the Board has an active role in corporate governance as well as the Board's financial commitment to shareholders and the provision of strategic oversight and direction [32].

The Agency's theory states that the function of the board of directors is an internal control tool that works to protect shareholders' interests from the opportunistic behavior of managers and to reconcile the interests of managers and shareholders [33]. However, previous studies have focused on studying the relationship between the structure of the board of directors and the value of the company [34] [35] [36], while in fact the independence of the board, the size of the board and the CEO duality are important elements of the literature.

This study is distinguished from previous studies that examined the relationship between the Board of Director's characteristics and tax aggressiveness on Jordanian companies listed on the Amman Stock Exchange. This study is the first of its kind in Jordan, which studied this relationship. In addition, this study provides important and useful information to the Income and Sales Tax Department to reduce tax aggressiveness and increase tax compliance among taxpayers, especially at a time when the budget in Jordan suffers from a huge fiscal deficit and increase the volume of external indebtedness.

\subsection{Board Composition and Tax Aggressiveness}

Shareholders typically limit the behavior of managers and maintain their interests in the company by influencing the board of directors, this effect may be useless when managers control the board [37] [38]. In addition, the composition of the Board of Directors is directly influenced by its ownership structure [39]. Previous studies on how the composition of the board affects oversight and hence its impact on corporate performance suggests that larger boards with more internal directors lead to agency problems than firms with smaller boards and fewer internal directors [18] [40] [41]. According to the previous discussion, the following hypotheses are developed:

$\mathrm{H1}$ : There is a negative relationship between board composition and tax ag- 
gressiveness.

\subsection{Board Independence and Tax Aggressiveness}

Because of the experience of the board members, they perform the monitoring function mainly, and they enjoy more incentives and benefits than internal managers because of their great professional experience [42] [43]. In addition, the independence of the board from management usually provides protection for shareholders from abusive management behaviors [44]. In developed countries, studies have shown that the independence of the board is linked to effective oversight and an effective corporate governance tool [45] [46] [47]. Furthermore, previous studies have indicated contradictory results regarding the effects of independent managers. Several studies have indicated that there is a positive relationship between the independence of board members and oversight of the performance and conduct of management [46] [48]. Quite the contrary, some studies suggest that the effectiveness of independent board members is politically linked and therefore their performance is not independent [49].

The presence of independent directors is a balance force in the board, and the presence of independent directors reinforces the elements of good governance in the company [50]. [19] found that the increase in the independence of board members leads to a reduction in the actual tax rate and has shown that good corporate governance elements lead to a strict tax policy. Moreover, through the role of board members as supervisors of the company's strategic decisions, they should support the interests of the owners and influence the level of tax aggressiveness [51]. In addition, [43] asserts that directors are directly responsible for monitoring management decisions.

Previous studies indicate that the relationship between independent managers and their effectiveness in tax administration from their accumulated experience is negative, as the independence of directors has a negative relationship with the potential for tax aggressiveness [18] [52] [53]. [31] also noted that the presence of more independent external directors is negatively associated with the potential for tax aggressiveness, and that the existence of independent boards with good corporate governance rules significantly reduces the potential for tax aggressiveness [31]. Moreover, several studies have indicated that the quality of board members rather than their independence has to do with reducing the likelihood of tax aggressiveness [54]. According to the previous discussion, we can improve the following hypothesis relating to the theory as below:

H2: There is a negative relationship between board independence and tax aggressiveness.

\subsection{CEO Duality and Tax Aggressiveness}

CEO duality means that the $\mathrm{CEO}$ of the company works as a chairperson of the board of directors. According to agency theory, and to increase the effectiveness of the corporate control system, the function of the CEO should be separated 
from the Chairman position [55]. However, there are many benefits of CEO duality like authorize $\mathrm{CEO}$ to handle firmly and own various point views on the firms. At the same time, there are many disadvantages for CEO duality like lack of transparency, in addition to gaining more power that leads to interest in their personal interests and makes decisions at the expense of external shareholders. Moreover, duality may lead to more corruption and resort to fraudulent methods in the absence of regulatory controls for these two positions in the decision-making process [39].

[3] suggested that agency cost come from weak corporate governance applications. However, Due to the separation of ownership and control, managers have a great incentive to exploit the company's resources at the expense of shareholders. Generally, the problems of the agency are more severe when managers have control over the board member, and this happens when the CEO duality and When the board of directors is composed of internals [56]. As a result, CEO duality leads to a decrease of the firm value, but it is characterized by lower expenses due to the possibility of aggressiveness [18]. Based on the above, the following hypothesis is developed:

H3: There is a positive relationship between CEO duality and tax aggressiveness.

\section{Methodology}

\subsection{Sample and Data Collection}

This study examines the relationship between corporate governance structure as reflected by the board of directors' composition, independence, and CEO duality from one side, and the tax aggressiveness of firms. To achieve the objective of the study, we use all publically listed companies in Jordan. However, we exclude those firms classified under the financial sector due to their distinct nature as they are subject to a different set of regulations and corporate governance instructions. Firms' data of five years is collected for sample firms, specifically during the period 2013-2017. The secondary data of all study variables were collected from the annual reports of sample firms, which is available on a public domain of Amman Stock Exchange (ASE). The initial sample consists of 140 firms but 11 firms were excluded due to the unavailability of their annual reports. The final sample consists of 129 firms where a total of645 firm-year are included in our analysis.

\subsection{Dependent Variable}

This study used different variables to test the relationship between board of director's attributes and tax aggressiveness. The dependent variable is the corporate tax aggressiveness. Literatures used many measures of tax aggressiveness such as cash effective tax rate, book-tax difference measures and a residual book-tax difference [27] [57] [58]. This study used the effective tax rate (ETR) to measure the tax aggressiveness. This study uses ETR as a measure for tax aggres- 
siveness as tax researches found it an excellent measure [59].

The effective tax rate is defined as the total tax income divide by pretax income.

$$
\mathrm{ETR}=\text { TOTAL TAX INCOME } \div \text { PRETAX INCOME }
$$

Aggressive tax planning can be measured by ETR using permanent book-tax differences. However, aggressive tax planning includes investment in tax-favored assets or tax exempt.

\subsection{Independent Variables}

Literature (e.g. [60] [61] [62]) found that specific board structures lead to reduce the agency problems and improve firm performance. This study examines Board Composition, Board independence and CEO duality. The proportion of outside independent directors determines board composition while board independence represents the percentage of independent directors on the board. Additionally, CEO duality means that the CEO of the company work as a chairperson of the board of directors. Following [18], the variable was assigned the value of 1 if the CEO of the company work as a chairperson of the board of directors, otherwise 0 .

\subsection{Conceptual Framework}

In Figure 1, we illustrate the conceptual framework of this research and the relationships between the study variables. The left side shows the board of director's attributes (independent variables), which indicated in corporate governance code in Jordan and the related literature. These variables are: Board Composition, Board independence and CEO duality. The right side shows the dependent variable (corporate tax aggressiveness).

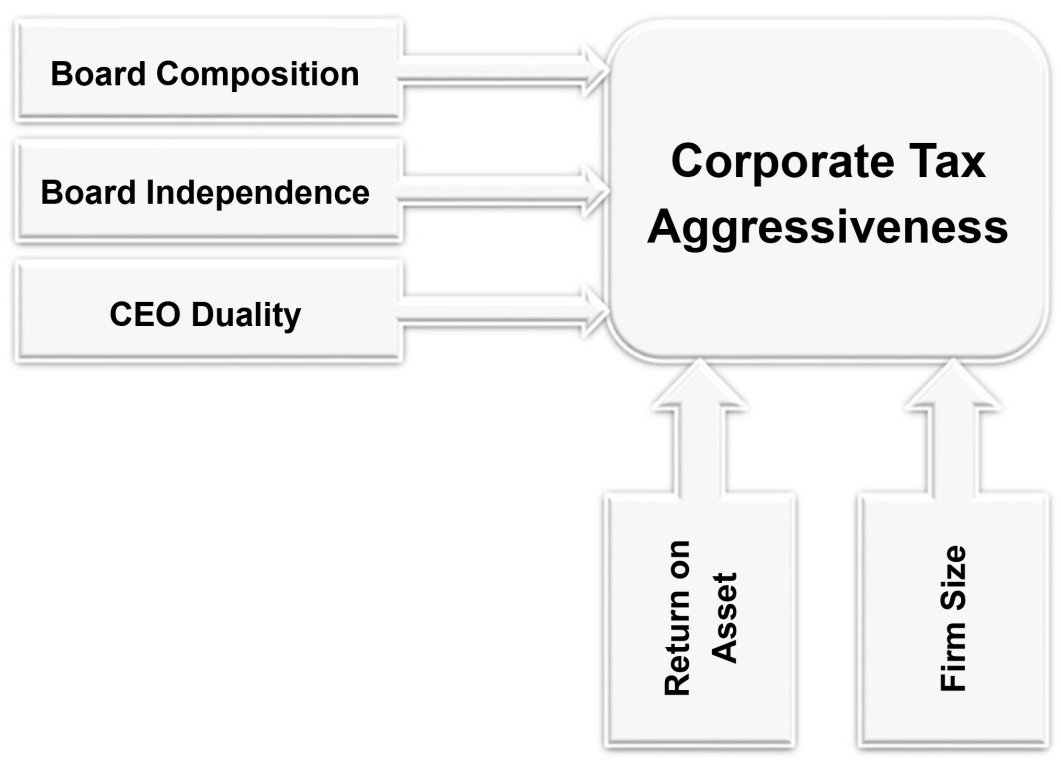

Figure 1. The conceptual framework of the study. 


\subsection{Control Variables}

To control for the possible effect of profitability and the firm's size on the relationship between corporate governance structure and tax aggressiveness, the study model included two control variable. The first variable is return on assets (ROA) which is operating income divided by total assets. Firms seek to develop business performance thorough develop tax optimization. (ROA) is usually used to control the firm performance and highlight the specific effect of tax optimization [18]. Since literature found that there is a positive relationship between the effective tax rate and firm size [29], the second control variable used in this study is the firm size (FIRMSZ). The natural log of the book value of the total asset is used to measure the firm size.

This study used logarithmic regression model to test the relationship between board directors' characteristics and tax aggressiveness. This model is useful for this kind of study because it is one of the transformations useful in data analysis to attain a packet data that most closely matches the standard form. The following regression model is used:

$$
\begin{aligned}
\ln \mathrm{ETR}_{i t}= & \propto 0+\propto 1 \ln \mathrm{COMP}_{i t}+\propto 2 \ln \mathrm{BINDP}_{i t}+\propto 3 \mathrm{CEOD}_{i t} \\
& +\propto 4 \mathrm{ROA}_{i t}+\propto 5 \mathrm{FSZE}+\epsilon_{i t}
\end{aligned}
$$

The definition of the variables used in this study is listed in Table 1.

\section{Empirical Results and Discussion}

\section{Descriptive Statistics}

Table 2 shows a summary descriptive analysis of the study dependent and explanatory variables. The mean, standard deviation of the effective tax rate (ETR) is 0.146 (4.116). This means that this rate is less than the applicable legal tax rate which is $19.33 \%$. We note that the legal tax rate imposed by the Jordanian government does not reflect the tax that is actually collected from Jordanian companies. Moreover, the mean, standard deviation for the board composition is 0.186 (0.129). While, the mean, standard deviation for the board independence is 3.934 (0.184). Furthermore, more than $50 \%$ of the study firms have CEO duality. Additionally, the mean, standard deviation for the return on asset (ROA) is 0.147 (0.338).

Table 3 shows the correlation results, we note that the highest correlation is between firm size and board composition and is (0.421). All other correlations are not high.

Table 4 shows the Regression Analysis Results, we note that the $R^{2}$ square is 0.182 which mean $18.2 \%$ of effective tax rate (ETR) variability can be explained by the independent variables. We also note that the lowest p-value from the study independent variable is return on assets (ROA) with p-value equal to 0.000 . However, it is the most significant variable between the study control variables. Furthermore, we note that the p-value for the firm size (FSIZE) is 0.006 . Additionally, this study control variables (ROA, FSIZE) are related to the study dependent variable (ETR) significantly. 
Table 1. Definition and measurement of variables.

\begin{tabular}{|c|c|c|}
\hline Variable & Definition & Measurement \\
\hline ETR & Effective Tax Rate & Total income divided by pretax income \\
\hline BCOMP & Board Composition & $\begin{array}{l}\text { the number of outside directors divided } \\
\text { by total number of directors }\end{array}$ \\
\hline BINDP & Board Independence & $\%$ of independent directors on the board \\
\hline CEOD & CEO Duality & if the CEO is also chairman of the board, 0 otherwise 1 \\
\hline ROA & Return on Assets & Operating income divided by total assets. \\
\hline FSZE & Firm Size & The natural log of the book value of the total asset \\
\hline
\end{tabular}

Table 2. Descriptive statistics of variables.

\begin{tabular}{ccccc}
\hline Variables & Mean & Minimum & Maximum & Standard Deviation \\
\hline ETR & 0.146 & -0.385 & 5.927 & 4.116 \\
BCOMP & 0.186 & 0 & 0.853 & 0.129 \\
BINDP & 3.934 & 0 & 0.768 & 0.184 \\
CEOD & 0.522 & 0 & 1 & 0.359 \\
ROA & 0.147 & -0.395 & 3.672 & 0.338 \\
FSZE & 8.094 & 5.379 & 11.551 & 1.294 \\
\hline
\end{tabular}

Table 3. correlation results.

\begin{tabular}{cccccc}
\hline Variable & BCOMP & BINDP & CEOD & ROA & FSZE \\
\hline BCOMP & 1.000 & & & & \\
BINDP & 0.073 & 1.000 & & & \\
CEOD & 0.117 & -0.047 & 1.000 & & \\
ROA & -0.097 & -0.211 & -0.154 & 1.000 & \\
FSZE & 0.421 & 0.318 & -0.057 & -0.224 & 1.000 \\
\hline
\end{tabular}

Table 4. Regression analysis results.

\begin{tabular}{cccc}
\hline Variable & Coefficient & $\mathrm{Z}$ & $\mathrm{P}>|\mathrm{z}|$ \\
\hline BCOMP & 0.113 & 1.832 & $0.079^{*}$ \\
BINDP & 0.177 & 1.547 & $0.067^{*}$ \\
CEOD & -1.342 & -2.178 & $0.017^{* *}$ \\
ROA & 0.264 & 5.653 & $0.000^{* * *}$ \\
FSZE & 1.346 & 2.489 & $0.006^{* * *}$ \\
Intercept & 1.105 & -2.328 & $0.012^{* *}$ \\
$R^{2}$ & & 0.182 & \\
\hline
\end{tabular}

${ }^{*}$ Significance at the $10 \%$ level; ${ }^{* *}$ significant at the $5 \%$ level; ${ }^{* * *}$ significance at the $1 \%$ level.

The board composition variable (BCOMP) is significant at the $10 \%$ level. It is indicating that board composition as one of corporate governance variables is 
most likely to have a relationship with the ETR. The positive sign of the coefficient for this variable implies that the increase in the percentage of outsiders decreases the activity of tax aggressiveness, confirming our H1 hypothesis. Additionally, the regression coefficients result for board independence (BINDP) is significant at the $10 \%$ level. It is indicating that board independence as one of corporate governance variables is most likely to have a relationship with the ETR. The positive sign of the coefficient for this variable implies that the increase in independent board decreases the activity of tax aggressiveness, confirming our $\mathrm{H} 2$ hypothesis. However, the regression coefficients result for board duality (BDUAL) is significant at the $5 \%$ level. It is indicating that board independence, as one of corporate governance variables is most likely to have a relationship with the ETR. The negative sign of the coefficient for this variable implies that the increase in duality board increases the activity of tax aggressiveness, confirming our $\mathrm{H} 3$ hypothesis.

\section{Conclusions}

This study examines the relationship between corporate governance characteristics and tax aggressiveness in a context of developing country. Using a study sample of 140 firms during the period 2013-2017, we run a regression model to examine the effect of board composition, board independence, CEO duality, ROA and firm size on the tax aggressiveness. Consistent with the previous studies conducted in the context of developed countries [24], we report evidence of a negative relationship between board composition and tax aggressiveness. The findings in this study imply that the presence of external members in the Board of Directors reduces the agency problem and hence moderates corporate tax aggressiveness practices. Moreover, this study documents a negative relationship between board independence and tax aggressiveness. This finding is consistent with the agency theory expectation. Further, this study finds that there is a positive relationship between board duality and tax aggressiveness. Finally, the return on assets and firm size is positively associated with the effective tax rate.

There are several implications for the corporate practice, the Income and Sales Tax Department and regulators. Since taxation is the main resource of the public budget in Jordan. Higher tax burden on taxpayers and tax aggressiveness may negatively affect the aggregate tax collection. Further, firms' implementation of corporate governance best practices can send signals of compliance with the tax rules and mitigate tax evasion practices.

There are several limitations in this study, which could open aspires for future research. First, external corporate governance mechanisms (i.e. institutional and debtholders monitoring) are not considered in this study. Second, there is a draft proposal to change the current status of corporate governance code in Jordan from a soft-law (i.e. comply or explain approach) to become statutory, which would reduce the future relevance of our findings. Finally, developing countries substantially vary in terms of tax policies as well as the reliance on the market-based 
finance and, therefore, the generalizability of our findings on all developing countries could be questionable. For future research, additional corporate governance mechanisms can be added to our model and datasets from different developing countries can be used to enhance generalizability.

\section{Conflicts of Interest}

The authors declare no conflicts of interest regarding the publication of this paper.

\section{References}

[1] Berle, A. and Means, G. (1932) The Modern Corporation and Private Property. Macmillan, New York.

[2] Coase, R. (1937) The Nature of the Firm. Economica, 4, 386-405. https://doi.org/10.1111/j.1468-0335.1937.tb00002.x

[3] Jensen, M. and Meckling, W. (1976) Theory of the Firm: Managerial Behaviors, Agency Cost and Ownership Structure. Journal of Financial Economics, 3, 305-360. https://doi.org/10.1016/0304-405X(76)90026-X

[4] Williamson, O. (1975) Markets and Hierarchies: Analysis and Antitrust Implications. Free Press, New York.

[5] Williamson, O. (1985) The Economic Institutions of Capitalism. Free Press, New York.

[6] Grossman, S. and Hart, O. (1986) The Cost and Benefits of Ownership: A Theory of Vertical and Lateral Integration. Journal of Political Economy, 94, 691-719. https://doi.org/10.1086/261404

[7] Hart, O. and Moore, J. (1990) Property Rights and the Nature of the Firm. Journal of Political Economy, 98, 1119-1158. https://doi.org/10.1086/261729

[8] Cohen, J., Krisnamoorthy, G. and Wright, A.M. (2002) Corporate Governance and the Audit Process. Contemporary Accounting Research, 194, 573-594. https://doi.org/10.1506/983M-EPXG-4Y0R-J9YK

[9] Alchian, A. and Demsetz, H. (1972) Production, Information Costs and Economic Organization. American Economic Review, 62, 777-795.

[10] Maali, B.M. and Al-Attar, A. (2017) Corporate Disclosure and Cultural Values: A Test for Multinational Corporations. The Journal of Developing Areas, 51, 251-265. https://doi.org/10.1353/jda.2017.0071

[11] Li, H.Z., Terjesen, S. and Umans, T. (2018) Corporate Governance in Entrepreneurial Firms: A Systematic Review and Research Agenda. Small Business Economics, 1-32. https://doi.org/10.1007/s11187-018-0118-1

[12] Ibrahim, M.H. and Law, S.H. (2014) Social Capital and $\mathrm{CO}_{2}$ Emission-Output Relations: A Panel Analysis. Renewable and Sustainable Energy Reviews, 29, 528-534. https://doi.org/10.1016/j.rser.2013.08.076

[13] Khurana, I.K. and Moser, W.J. (2012) Institutional Shareholders' Investment Horizons and Tax Avoidance. The Journal of the American Taxation Association, 35, 111-134. https://doi.org/10.2308/atax-50315

[14] Mahenthiran, S. and Kasipillai, J. (2012) Influence of Ownership Structure and Corporate Governance on Effective Tax Rates and Tax Planning: Malaysian Evidence. Australian Tax Forum, 27, 941-969. https://doi.org/10.2139/ssrn.2384718 
[15] Landry, S., Deslandes, M. and Fortin, A. (2013) Tax Aggressiveness, Corporate Social Responsibility and Ownership Structure. Journal of Accounting, Ethics and Public Policy, 14, 611-645. https://doi.org/10.2139/ssrn.2304653

[16] Salihu, I.A. (2014) Investigating the Determinants of Corporate Tax Avoidance among Malaysian Public Listed Companies. Doctoral Dissertation, International Islamic University Malaysia, Kuala Lumpur.

[17] Hanlon, M. and Heitzman, S. (2010) A Review of Tax Research. Journal of Accounting and Economics, 50, 127-178. https://doi.org/10.1016/j.jacceco.2010.09.002

[18] Minnick, K. and Noga, T. (2010) Do Corporate Governance Characteristics Influence Tax Management? Journal of Corporate Finance, 16, 703-718. https://doi.org/10.1016/j.jcorpfin.2010.08.005

[19] Yeung, C.T. (2010) Effects of Corporate Governance on Tax Aggressiveness. An Honors Degree Project, Hong Kong Baptist University, Hong Kong.

[20] Scholes, M., Wolfson, M., Erickson, M., Maydew, E. and Shevlin, T. (2005) Taxes and Business Strategy: A Planning Approach. 3rd Edition, Pearson Prentice Hall, Upper Saddle River.

Schulze, W.S., Lubatkin, M., Dino, R. and Buchholtz, A. (2001) Agency Relationships in Family Firms: Theory and Evidence. Organization Science, 12, 99-116. https://doi.org/10.1287/orsc.12.2.99.10114

[21] Jaradat, M.S. (2015) Corporate Governance Practices and Capital Structure: A Study with Special Reference to Board Size, Board Gender, outside Director, and CEO Duality. International Journal of Economics, Commerce and Management, 3, 264-273.

[22] Huseynov, F. and Klamm, B.K. (2012) Tax Avoidance, Tax Management and Corporate Social Responsibility. Journal of Corporate Finance, 18, 804-827. https://doi.org/10.1016/j.jcorpfin.2012.06.005

[23] Esa, E. and Mohd Ghazali, N.A. (2012) Corporate Social Responsibility and Corporate Governance in Malaysian Government-Linked-Companies. Corporate Governance, 12, 292-305. https://doi.org/10.1108/14720701211234564

[24] Zemzem, A. and Ftouhi, K. (2013) The Effects of Board of Directors' Characteristics on Tax Aggressiveness. Research Journal of Finance and Accounting, 4, 140-147.

[25] Gomes, A.P.M. (2016) Corporate Governance Characteristics as a Stimulus to Tax Management. Revista Contabilidade and Finanças, 27, 149-168. https://doi.org/10.1590/1808-057x201500750

[26] Bosun-Fakunle, Y.F. and Josiah, M. (2019) Board of Directors Characteristics and Tax Aggressiveness. International Journal of Management Science Research, 5, 133-152.

[27] Desai, M.A. and Dharmapala, D. (2006) Corporate Tax Avoidance and High-Powered Incentives. Journal of Financial Economics, 79, 145-179. https://doi.org/10.1016/j.jfineco.2005.02.002

[28] Chen, S., Chen, X., Cheng, Q. and Shevlin, T. (2010) Are Family Firms More Tax Aggressive than Non-Family Firms? Journal of Financial Economic, 95, 41-61. https://doi.org/10.1016/j.jfineco.2009.02.003

[29] Hanlon, M. and Slemrod, J. (2009) What Does Tax Aggressiveness Signal? Evidence from Stock Price Reactions to News about Tax Shelter Involvement. Journal of Public Economics, 93, 126-141. https://doi.org/10.1016/j.jpubeco.2008.09.004

[30] Li, Y.W., Gong, M.F., Zhang, X.-Y. and Koh, L. (2018) The Impact of Environmental, Social, and Governance Disclosure on Firm Value: The Role of CEO Power. The 
British Accounting Review, 50, 60-75. https://doi.org/10.1016/j.bar.2017.09.007

[31] Lanis, R. and Richardson, G. (2011) The Effect of Board of Director Composition on Corporate Tax Aggressiveness. Journal of Accounting and Public Policy, 30, 50-70. https://doi.org/10.1016/j.jaccpubpol.2010.09.003

[32] Owens, J.P. (2008) Good Corporate Governance: The Tax Dimension. Springer, New York.

[33] Jensen, M. (1993) The Modern Industrial Revolution, Exit, and the Failure of Internal Control Systems. Journal of Finance, 48, 831-881. https://doi.org/10.1111/j.1540-6261.1993.tb04022.x

[34] Peng, M.W. (2004) Outside Directors and Firm Performance during Institutional Transitions. Strategic Management Journal, 25, 453-471. https://doi.org/10.1002/smj.390

[35] Chen, K.P. and Chu, C.Y.C. (2006) Internal Control vs. External Manipulation: A Model of Corporate Income Tax Evasion. RAND Journal of Economics, 36, 151-164.

[36] Shaukat, A., Qiu, Y. and Trojanowski, G. (2016) Board Attributes, Corporate Social Responsibility Strategy, and Corporate Environmental and Social Performance. Journal of Business Ethics, 135, 569-585. https://doi.org/10.1007/s10551-014-2460-9

[37] Bai, C.E., Liu, Q., Lu, J., Song, F.M. and Zhang, J.X. (2004) Corporate Governance and Market Valuation in China. Journal of Comparative Economics, 32, 599-616. https://doi.org/10.1016/j.jce.2004.07.002

[38] Landi, G. and Sciarelli, M. (2018) Towards a More Ethical Market: The Impact of ESG Rating on Corporate Financial Performance. Social Responsibility Journal, 15, 11-27. https://doi.org/10.1108/SRJ-11-2017-0254

[39] Lin, B., Lu, R. and Zhang, T. (2012) Tax-Induced Earnings Management in Emerging Markets: Evidence from China. Journal of the American Taxation Association, 34, 19-44. https://doi.org/10.2308/atax-10236

[40] Yermack, D. (1996) Higher Market Valuation of Companies with a Small Board of Directors. Journal of Financial Economics, 40, 85-211. https://doi.org/10.1016/0304-405X(95)00844-5

[41] Core, J., Holthausen, R. and Larcker, D. (1999) Corporate Governance, Chief Executive Officer Compensation, and Firm Performance. Journal of Financial Economics, 51, 371-406. https://doi.org/10.1016/S0304-405X(98)00058-0

[42] Beasley, M.S. (1996) An Empirical Analysis of the Relation between the Board of Director Composition and Financial Statement Fraud. The Accounting Review, 71, 443-465.

[43] Fama, E.F. and Jensen, M.C. (1983) Separation of Ownership and Control. Journal of Law and Economics, 26, 301-325. https://doi.org/10.1086/467037

[44] Hu, H.W., Tam, O.K. and Tan, M.G.S. (2010) Internal Governance Mechanisms and Firm Performance in China. Asia Pacific Journal of Management, 27, 727-749. https://doi.org/10.1007/s10490-009-9135-6

[45] Hermalin, B.E. and Weisbach, M.S. (2003) Boards of Directors as an Endogenously Determined Institution: A Survey of the Economic Literature. Economic Policy Review, 9, 7-26.

[46] Peasnell, K.V., Pope, P.F. and Young, S. (2005) Board Monitoring and Earnings Management: Do Outside Director's Influence Abnormal Accruals? Journal of Business Finance and Accounting, 32, 1311-1346. https://doi.org/10.1111/j.0306-686X.2005.00630.x 
[47] Chang, Y.K., Oh, W.Y., Jung, J.C. and Lee, J.Y. (2012) Firm Size and Corporate Social Performance: The Mediating Role of Outside Director Representation. Journal of Leadership \& Organizational Studies, 19, 486-500. https://doi.org/10.1177/1548051812455239

[48] Bouslah, K., Linares-Zegarra, J., M'Zali, B. and Scholtens, B. (2018) CEO Risk-Taking Incentives and Socially Irresponsible Activities. The British Accounting Review, 50, 76-92. https://doi.org/10.1016/j.bar.2017.05.004

[49] Qiu, H.Y. and Yao, S.H. (2009) Share Merger Reform, Corporate Governance and Firm Value in China. In: 22nd Australasian Finance and Banking Conference, University of Hong Kong Working Paper, Hong Kong, 1-44. https://doi.org/10.2139/ssrn.1275699

[50] Bhagat, S. and Bolton, B. (2008) Corporate Governance and Firm Performance. Journal of Corporate Finance, 14, 257-273. https://doi.org/10.1016/j.jcorpfin.2008.03.006

[51] Ibrahim, N.A. and Angelidis, J.P. (1995) The Corporate Social Responsiveness Orientation of Board Members: Are There Differences between Inside and Outside Directors? Journal of business Ethics, 14, 405-410. https://doi.org/10.1007/BF00872102

[52] Klein, A. (2006) Audit Committee, Board of Director Characteristics, and Earnings Management. NYU Working Paper No. 2451/27450, 1-39.

[53] Firth, M., Fung, P.M.Y. and Rui, O.M. (2007) How Ownership and Corporate Governance Influence Chief Executive Pay in China's Listed Firms? Journal of Business Research, 60, 776-785. https://doi.org/10.1016/j.jbusres.2007.01.014

[54] Sarkar, J., Sarkar, S. and Sen, K. (2008) Board of Directors and Opportunistic Earnings Management: Evidence from India. Journal of Accounting, Auditing and Finance, 23, 517-551. https://doi.org/10.1177/0148558X0802300405

[55] Maali, B.M. and Jaara, O.O. (2014) Reality and Accounting: The Case for Interpretive Accounting Research. International Journal of Accounting and Financial Reporting, 4, 155. https://doi.org/10.5296/ijafr.v4i1.5468

[56] Li, J.Y. (2007) Fundamental Enterprise Income Tax Reform in China: Motivations and Major Changes. Comparative Research in Law and Political Economy. Research Report No. 33. https://doi.org/10.2139/ssrn.1030656

[57] Manzon, G. and Plesko, G. (2002) The Relation between Financial and Tax Reporting Measures of Income. Tax Law Review, 55, 175-214.

[58] Hanlon, M. and Shevlin, T. (2002) The Tax Benefits of Employee Stock Options: The Accounting and Implications for Research. Accounting Horizons, 16, 1-16. https://doi.org/10.2308/acch.2002.16.1.1

[59] Armstrong, C.S., Blouin, J.L. and Larcker, D.F. (2012) The Incentives for Tax Planning. Journal of Accounting and Economics, 53, 391-411.

https://doi.org/10.1016/j.jacceco.2011.04.001

[60] Gaur, S.S., Bathula, H. and Singh, D. (2015) Ownership Concentration, Board Characteristics and Firm Performance: A Contingency Framework. Management Decision, 53, 911-931. https://doi.org/10.1108/MD-08-2014-0519

[61] Singh, S., Tabassum, N., Darwish, T.K. and Batsakis, G. (2018) Corporate Governance and Tobin's Q as a Measure of Organizational Performance. British Journal of Management, 29, 171-190. https://doi.org/10.1111/1467-8551.12237

[62] Martin, G.P., Wiseman, R.M. and Gomez-Mejia, L.R. (2019) The Interactive Effect of Monitoring and Incentive Alignment on Agency Costs. Journal of Management, 45, 701-727. https://doi.org/10.1177/0149206316678453 